Research paper

\title{
Harvesting eucalyptus energy plantations in Brazil with a modified New Holland forage harvester
}

\author{
Saulo Philipe Sebastião Guerra ${ }^{a}$, Guilherme Oguri a , Raffaele Spinelli b, * \\ a Sao Paulo State University, College of Agricultural Sciences (UNESP/FCA), Jose Barbosa Barros St 1780, Botucatu, Sao Paulo, Brazil \\ b CNR IVALSA, Via Madonna del Piano 10, Sesto Fiorentino (FI), Italy
}

\section{A R T I C L E I N F O}

\section{Article history:}

Received 24 November 2015

Received in revised form

8 January 2016

Accepted 15 January 2016

Available online 24 January 2016

\section{Keywords:}

Biomass

Productivity

Efficiency

SRC

Wood chip

\begin{abstract}
A B S T R A C T
Modified foragers represent a cost-effective option for harvesting high-density short-rotation energy plantations. However, new energy plantations grown in Brazil far exceed the stocking and the stem size characterizing plantations in the Northern hemisphere, which raises the question about the ability of modified foragers to perform effectively. A study was conducted on five eucalyptus plantations, located in different Brazilian States and spanning over a wide range of work conditions in terms of clone, age, planting density and row system (e.g. single or twin rows). Field stocking varied between 90 and $157 \mathrm{t} \mathrm{ha}^{-1}$, and breast-height diameter between 5 and $8 \mathrm{~cm}$. The tests were conducted with a New Holland 9060 forager, equipped with a 130 FB energy wood header. This machine was capable of negotiating all test fields, and reached a productivity on these sites between 39 and $65 \mathrm{t} \mathrm{h}^{-1}$, which was comparable with the productivity values recorded in Europe and North America. The machine coped well with the high field stocking and stem size levels encountered in Brazil. Blockages accounted for a very small proportion of total harvesting time, which was similar to that recorded in studies conducted on poplar and willow in the Northern hemisphere. Productivity was directly proportional to field stocking and target chip length. Changing target chip length from 30 to $20 \mathrm{~mm}$ resulted in a $20-30 \%$ reduction in productivity. These figures reflect work conditions in uncoppiced first-rotation plantations, and they should be applied with some caution to following rotations.
\end{abstract}

() 2016 Elsevier Ltd. All rights reserved.

\section{Introduction}

Plantation forests are playing an increasingly important role in industrial wood fibre supply, and may satisfy most of the global demand in the near future [1]. Modern industrial tree plantations implement all the latest advances in genetic improvement and rationalized cropping techniques, which result in very high growth rates and short rotation lengths [2]. The availability of land and labour at relatively low cost has resulted in a strong expansion of industrial plantations in the Southern Hemisphere [3,4].

Plantation forestry is particularly strong in Brazil, where it covers over 6 million hectares, and yields 184 million $\mathrm{m}^{3}$ of round wood annually [5]. Favourable soil and climate conditions, together with the gains from genetic improvement of crops, result in exceptional growth rates [6]. What is more, the area invested with

\footnotetext{
* Corresponding author.

E-mail addresses: ssguerra@fca.unesp.br (S.P.S. Guerra), goguri@fca.unesp.br (G. Oguri), spinelli@ivalsa.cnr.it (R. Spinelli).
}

fast growing plantations in Brazil is expected to grow dramatically over the next decades [7]. Eucalyptus is the most common genus used for establishing industrial forest plantations in Brazil, and also the most successful one. The majority of Brazilian eucalyptus plantations are characterized by a $3 \times 2 \mathrm{~m}$ spacing, a rotation age between 5 and 7 years, and yields in excess of $270 \mathrm{~m}^{3}$ of pulpwood per hectare [8]. These plantations are geared to support large modern pulp mills, and are often established in the immediate vicinity of the mills they supply [9].

In recent years, the increasing demand for renewable energy feedstock has raised interest in growing eucalyptus for biomass fuel production [10]. The quality requirements of biomass fuel are lower than for pulpwood, which may permit higher densities and shorter rotations in order to maximize mass yield [11]. New high-density plantations are established at a density between 3300 and 14,000 trees ha ${ }^{-1}$, are managed as short-rotation coppice (SRC) and are cut every second or third year, yielding up to $100 \mathrm{t} \mathrm{ha}^{-1}$ dry matter, or $1000 \mathrm{GJ} \mathrm{ha}^{-1}$ [12]. Under these conditions, the conventional harvesting techniques designed for pulpwood production are not suitable, because sub-optimal stem size results in low productivity 
and high harvesting cost. Unfortunately, industrial crops are specifically designed to produce large quantities of low-priced raw materials, and their success requires that all operations be conducted with the utmost efficiency. For this reason, conventional single-tree harvesting must be replaced with swathe harvesting, as already applied in European energy forests [13].

Brazilian energy biomass producers may simply adopt European harvesting technology, which is generally based on modified foragers and benefits from a long evolution [14]. However, Brazilian eucalyptus plantations offer bigger and harder trees than found in Europe, which is likely to affect harvester performance. Similar problems were found when introducing standard Nordic machines to Southern Europe [15] or to the northeastern USA [16], where stem size was significantly larger. Most forager-based SRC harvesters have maximum stem size and crop density limits, which change with machine type and design. European manufacturers have already ventured into developing larger and more powerful version of their SRC harvesters, in order to cope with the larger stem size characterizing new plantation models [13]. Nevertheless, these machines are still designed for European poplars and willows, which are generally shorter and weaker than Brazilian eucalyptus. Most forager designs struggle to lay down large trees, which tend to jam in the space between the cutting device and the feeding apparatus. In that case, one should favour designs with a wide infeed opening, unobstructed by flow dividers, slides or rollers.

All these requirements are found in the new SRC harvester developed by Case New Holland. This machine is quite powerful, and adopts a streamlined cut-and-feed device resembling the system already used on sugar cane harvesters. Such machine is specifically designed for industrial use, which is likely to be especially intense in Brazil, due to the large-scale industrial character of Brazilian forest industries. Furthermore, resemblance with conventional sugar cane harvesters represents a marked advantage in a country with a thriving sugar cane industry, where most local workshop are already familiar with such technology.

The goal of this study was to determine the performance of this new forager-based cut-and-chip harvester, deployed for the first time on Brazilian SRC eucalyptus. In fact, this would be the first attempt at harvesting Brazilian SRC eucalyptus with a foragerbased harvester, regardless of harvester make and model. In particular, the authors set out to determine harvesting productivity and fuel efficiency, and to model them as a function of specific work conditions.

\section{Materials and methods}

The machine used for the test was the $441 \mathrm{~kW}$ New Holland FR9060 forager model, fitted with the dedicated 130FB header, which is specifically designed for harvesting large-size SRC. The header is fitted with a pair of large diameter circular saws placed at the bottom of the same shafts that carry the vertical crop collectors, and a horizontal paddle roll (Fig. 1). The saws cut the stems, while the crop collectors and the paddle roll move them towards the horizontal infeed rollers, which feed the stems to the chipping unit. The latter is located inside the forager proper, and consists of the same drum used for chopping maize, fitted with sixteen knives divided in two sections. Chips are engaged by the blower, and discharged through the outlet pipe. Target chip length can be adjusted to any value between 5 and $30 \mathrm{~mm}$, directly from the operator's seat. For the purpose of the study, the 20 and $30 \mathrm{~mm}$ lengths were selected because these were considered most suitable for energy production by the individual field owners. During the study, the machine was supported by two farm tractors pulling two trailers each. Individual trailers had a capacity between 8 and $35 \mathrm{~m}^{3}$, depending on availability at the test sites.

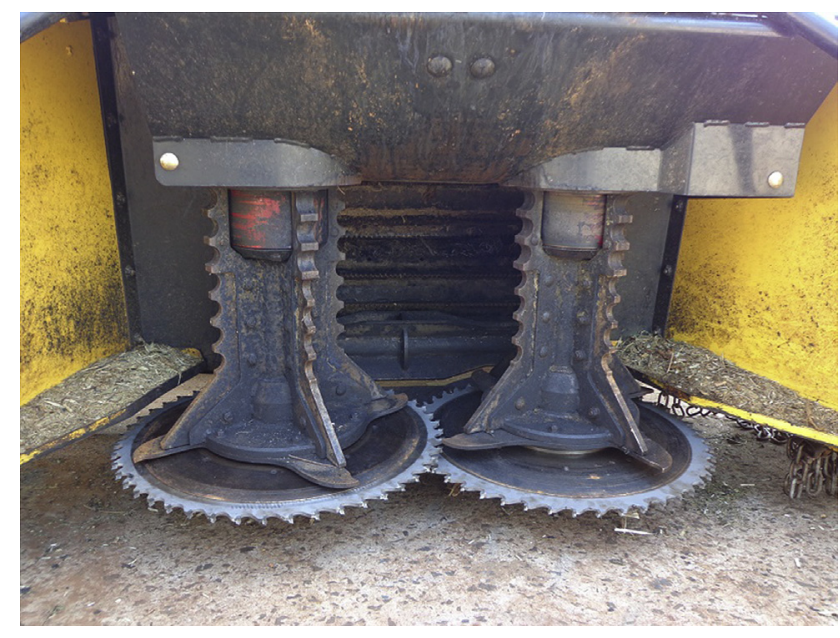

Fig. 1. Detailed view of the New Holland FB130 header

The test were conducted on 5 different plantations, chosen to cover the whole range of variation of Brazilian SRC eucalyptus. The plantations were established with different hybrid eucalyptus clones, at densities ranging from 3300 to 14,800 trees ha ${ }^{-1}$. The densest plantation (e.g.14,800 trees ha ${ }^{-1}$ ) had been established according to the twin-row system, while all the others had been planted as single rows. The plantations were spread across three States, and spanned a wide range of climatic conditions, but they all grew on well-drained soils in flat land (Table 1). During all tests, the machine was operated by the same driver, who was well acquainted with the base unit, but had been driving the harvester on the eucalyptus energy plantations for few weeks before commencing the test proper.

The research consisted of a set of detailed time-and-motion studies conducted at the cycle level [17]. The filling of a full trailer load of chips was assumed as a cycle, which began with the forward motion of the harvester discharging chips into an empty trailer, and ended when the chip trailer was full to capacity (Fig. 2). For each cycle, researchers determined the following parameters: surface area, biomass output, time input and fuel input.

The surface area covered with each cycle was determined by multiplying inter-row space by total travel length, the latter determined through the readings provided by the on-board computer. Resulting figures were double-checked with those obtained from a Garmin 60 CSX GPS device. Biomass output was estimated by measuring the volume of all chip trailers produced during each test, and by taking 20 sample trailers per field to a certified weighbridge. Bulk density figures obtained from the 20 sample trailers were applied to the measured volumes of all trailers produced during the test, in order to obtain fresh load weights. The moisture content of fresh chips was determined with the gravimetric method according to the ASABE S358.2 standard (2010): at least ten 500-g samples were randomly collected from the trailer loads, packed into sealed bags and dispatched to the laboratory for analysis. Once there, samples were placed in a ventilated oven and dried at the temperature of $103 \pm 2{ }^{\circ} \mathrm{C}$ for $72 \mathrm{~h}$, before weighing them again on a precision scale.

Time and fuel inputs were determined through on-board computer readings. The forager was equipped with the new "Intelliview" automatic data collection system that stored data about travel speed $\left(\mathrm{km} \mathrm{h}^{-1}\right)$, fuel use $\left(\mathrm{l} \mathrm{h}^{-1}\right)$, harvest time $(\mathrm{h})$ and harvest distance $(\mathrm{m})$. Time readings were checked against those provided by a conventional stopwatch and proved extremely accurate.

Researchers also determined the activity breakdown of total 
Table 1

Characteristics of the test sites.

\begin{tabular}{|c|c|c|c|c|c|c|}
\hline Field & & A & B & $\mathrm{C}$ & $\mathrm{D}$ & $\mathrm{E}$ \\
\hline Longitude & & $20^{\circ} 54^{\prime} \mathrm{S}$ & $15^{\circ} 46^{\prime} \mathrm{S}$ & $21^{\circ} 43^{\prime} \mathrm{S}$ & & \\
\hline Latitude & & $51^{\circ} 52^{\prime} \mathrm{W}$ & $42^{\circ} 07^{\prime} \mathrm{W}$ & $49^{\circ} 51^{\prime} \mathrm{W}$ & & \\
\hline Location & & Tres Lagoas & Taiboeiras & Lins & & \\
\hline State & & MS & MG & SP & & \\
\hline Elevation & $\mathrm{m}$ als & 320 & 750 & 444 & & \\
\hline Climate & & Semi-humid & Semi-arid & Tropical & & \\
\hline Soil type & & Oxisol-ultisol & Quartzous sand & Oxisol-ultisol & & \\
\hline Texture & & Sandy loam & Loamy sand & Loam & & \\
\hline Drainage & & Well drained & Very well drained & Well drained & & \\
\hline Slope & $\%$ & $0-5$ & $0-5$ & $0-5$ & & \\
\hline Annual rainfall & $\mathrm{mm}$ & 1400 & 855 & 1300 & & \\
\hline Mean temperature & $\mathrm{C}^{\circ}$ & 24 & 21 & 22 & & \\
\hline Surface & ha & 3.82 & 9.80 & 0.74 & 2.37 & 1.03 \\
\hline Species & & $\mathrm{EG} \times \mathrm{EU}$ & $\mathrm{EG} \times \mathrm{EU}$ & $\mathrm{EC} \times \mathrm{ET}$ & $\mathrm{EC} \times \mathrm{ET}$ & $\mathrm{EC} \times \mathrm{ET}$ \\
\hline Clone & & H1069 & $\mathrm{I} 144$ & $\mathrm{I} 144$ & C58 & C58 \\
\hline Age & years & 2.8 & 3.0 & 3.3 & 3.2 & 3.2 \\
\hline Rows & & single & single & single & single & twin \\
\hline Spacing & $\mathrm{m}$ & $3 \times 1$ & $4 \times 0.5$ & $3 \times 0.5$ & $3 \times 0.5$ & $2 \times 0,7 \times 0,5$ \\
\hline Plant density & trees ha ${ }^{-1}$ & 3333 & 5000 & 6666 & 6666 & 14,814 \\
\hline Yield & fresh $t \mathrm{ha}^{-1}$ & 90.1 & 129.8 & 157.2 & 141.8 & 97.1 \\
\hline Yield & fresh $\mathrm{t} \mathrm{ha}^{-1}$ year $^{-1}$ & 32.2 & 43.3 & 47.6 & 44.3 & 30.3 \\
\hline Yield & dry t ha ${ }^{-1}$ year $^{-1}$ & 14.2 & 19.9 & 19.7 & 18.8 & 13.3 \\
\hline $\mathrm{DBH}$ & $\mathrm{cm}$ & 8.1 & 6.6 & 7.5 & 7 & 5.4 \\
\hline Basal area & $\mathrm{M}^{2} \mathrm{ha}^{-1}$ & 16.7 & 14.3 & 24.5 & 19.6 & 16.6 \\
\hline
\end{tabular}

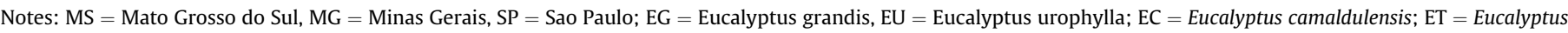
tereticornis; DBH = Diameter at breast height $(1.3 \mathrm{~m})$.

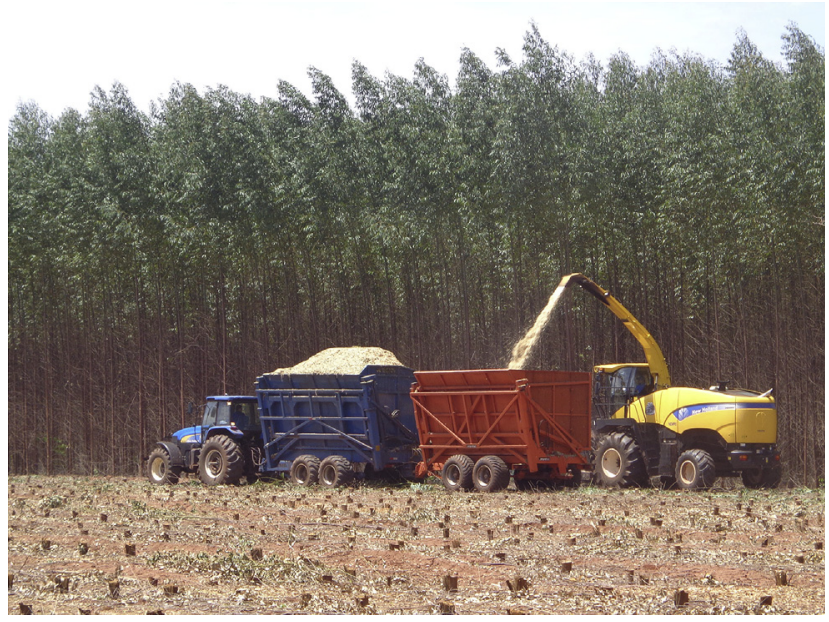

Fig. 2. The New Holland harvester at work in the eucalyptus energy plantations.

worksite time, on a subsample of 2 ha. Total worksite time was allocated to the following activities: harvesting, manoeuvre, waiting for containers and other delays. Harvesting and manoeuvre were considered as productive time, whereas the other activities fell into the delay category [18].

The dataset was analysed with the Statview advanced statistics software, in order to check the statistical significance of eventual trends. Before analysis, the data was tested for normality using Ryan-Noyer's test. The dataset was then checked for homoscedasticity using Bartlett's test. Normal, homoscedastic data were tested using the Tukey-Kramer test, which is especially suited to handle unbalanced datasets and is relatively powerful. In contrast, nonnormal and/or heteroscedastic data were handled with nonparametric and post-hoc tests, robust to violations of statistical assumptions, although less powerful than the Tukey-Kramer's test. In particular, the Kruskal-Wallis test was used for checking the presence of statistically significant differences between groups, and the Scheffe's post-hoc test for pinning such differences onto specific groups. Both such tests are suitable for data sets flawed by unequal numbers of observations, non-normal distribution of data and heteroscedasticity. Relationships were modelled through multiple linear regression analysis, after transforming those trends that did not show a linear behaviour. Target chip length and row system (single rows or twin rows) were considered as categorical variables and introduced in the regressions as indicator (dummy) variables. The effect of target chip length and row system were tested separately, because the only twin row field included in the study (field E) was harvested with the machine set for the $20 \mathrm{~mm}$ target chip length, and no observations were available for twin row harvesting under the $30 \mathrm{~mm}$ target chip length setting. For this reason, the effect of target chip length was tested after removing all observations collected in field E from the dataset, while the effect of the row system was tested after removing all observations obtained under the $30 \mathrm{~mm}$ target chip length setting. This way, one could work on two homogenous and balanced datasets. Compliance with the statistical assumptions was checked through the analysis of residuals. For all tests, the elected significance level was $\alpha<0.05$.

Tests were conducted in 2012 and 2013, covering 17.8 ha and producing $5610 \mathrm{~m}^{3}$ of loose chips, equal to 2170 green tonnes of chips or 231 trailers (observations). The valid time study sessions lasted $40.7 \mathrm{~h}$, excluding delay time.

\section{Results}

There were large variations in field size and stocking, as well as in the moisture content of harvested trees. Individual field size ranged from 0.7 to 9.8 ha, with an average of 3.6 ha. Field stocking varied between 90.1 and 157.2 fresh $\mathrm{tha}^{-1}$, with an average value of 123.2 fresh $\mathrm{t} \mathrm{ha}^{-1}$ (Table 1 ). Corresponding yields varied between 32.2 and 47.6 fresh $\mathrm{t} \mathrm{ha}^{-1}$ year $^{-1}$, with a mean value of 39.5 fresh $\mathrm{t}$ $\mathrm{ha}^{-1}$ year $^{-1}$. Moisture content averaged $56.4 \%$ but it showed significant variations among fields. In particular, it was lowest on field B compared with all other fields (Table 2). This field had been established with the same I144 clone used for field C, which produced significantly wetter wood (i.e 54 vs. 59\% moisture content, 
Table 2

Main results of the study: field stocking, machine productivity and fuel use.

\begin{tabular}{|c|c|c|c|c|c|c|c|c|c|c|c|c|c|c|c|}
\hline \multirow[t]{2}{*}{ Field } & & \multicolumn{2}{|l|}{ A } & \multicolumn{2}{|l|}{ B } & \multicolumn{2}{|l|}{$\mathrm{C}$} & \multicolumn{2}{|l|}{$\mathrm{D}$} & \multicolumn{2}{|l|}{$\mathrm{E}$} & \multicolumn{2}{|c|}{ Overall } & & \multirow[t]{2}{*}{ Test type } \\
\hline & & Mean & SD & Mean & SD & Mean & SD & Mean & SD & Mean & SD & Mean & SD & Sum & \\
\hline Observations & $\mathrm{n}$ & 22 & - & 100 & - & 21 & - & 66 & - & 22 & - & - & - & 231 & \\
\hline Surface & ha & 3.82 & - & 9.80 & - & 0.74 & - & 2.37 & - & 1.03 & - & 3.55 & 3.70 & 17.77 & \\
\hline Output & $\mathrm{t}$ & 344 & - & 1274 & - & 116 & - & 336 & - & 100 & - & 434 & 484 & 2170 & \\
\hline Stocking & $\mathrm{tha}^{-1}$ & $90.1^{\mathrm{a}}$ & 11.5 & $129.8^{\mathrm{b}}$ & 19.4 & $157.2^{\mathrm{C}}$ & 39.1 & $141.8^{\mathrm{bc}}$ & 46.9 & $97.1^{\mathrm{a}}$ & 39.3 & 123.2 & 37.9 & - & Tukey-Kremer \\
\hline Moisture content & $\%$ & $55.8^{\mathrm{ab}}$ & 2.1 & $54.1^{\mathrm{b}}$ & 2.4 & $58.6^{\mathrm{cd}}$ & 2.1 & $57.6^{\text {ad }}$ & 1.9 & $56.3^{\mathrm{ac}}$ & 2.2 & 56.4 & 2.6 & - & Tukey-Kremer \\
\hline Speed & $\mathrm{km} \mathrm{h}^{-1}$ & $1.42^{\text {ade }}$ & 0.33 & $1.26^{\mathrm{b}}$ & 0.18 & $1.12^{\mathrm{c}}$ & 0.07 & $1.35^{\mathrm{d}}$ & 0.18 & $1.49^{\mathrm{e}}$ & 0.28 & 1.31 & 0.22 & - & Tukey-Kremer \\
\hline Productivity & $\mathrm{t} \mathrm{h}^{-1}$ & $38.8^{\mathrm{a}}$ & 11.3 & $65.1^{\mathrm{b}}$ & 10.7 & $53.2^{\mathrm{C}}$ & 14.4 & $56.6^{\mathrm{c}}$ & 18.1 & $47.4^{\mathrm{ac}}$ & 15.8 & 57.4 & 16.3 & - & Tukey-Kremer \\
\hline Fuel use & $1 \mathrm{~h}^{-1}$ & $78.3^{\mathrm{a}}$ & 6.5 & $83.6^{\mathrm{bc}}$ & 5.3 & $86.5^{\mathrm{b}}$ & 6.8 & $80.9^{\mathrm{ac}}$ & 8.6 & $81.0^{\mathrm{ac}}$ & 5.9 & 82.3 & 6.9 & - & Scheffe \\
\hline Fuel use & $1 \mathrm{t}^{-1}$ & $2.2^{\mathrm{a}}$ & 0.6 & $1.3^{\mathrm{b}}$ & 0.2 & $1.8^{\mathrm{ac}}$ & 0.8 & $1.6^{\mathrm{c}}$ & 0.5 & $1.9^{\mathrm{ac}}$ & 0.7 & 1.6 & 0.6 & - & Scheffe \\
\hline Target chip length & $\mathrm{mm}$ & 30 & & 30 & - & 20 & - & 20 & - & 20 & - & - & - & - & \\
\hline
\end{tabular}

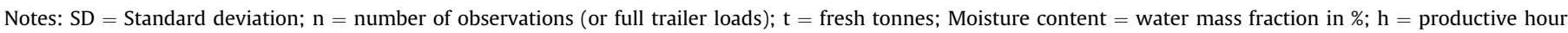

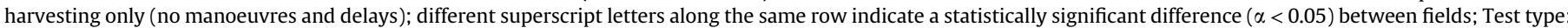

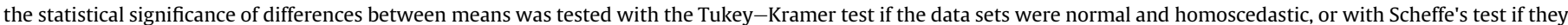
were non-normal and/or heteroscedastic.

respectively). Once moisture content was discounted, the actual yield in dry matter varied between 13.3 and 19.9 dry $t ~ h a^{-1}$ year $^{-1}$, with a mean value of 17.2 dry $\mathrm{t} \mathrm{ha}^{-1}$ year $^{-1}$.

Machine productivity ranged from 38.8 to $65.1 \mathrm{fresh} \mathrm{t} \mathrm{h}^{-1}$, when related to harvesting time, excluding manoeuvres and delays (Table 2). However, harvesting time did include occasional blockage of the header, due to the introduction of excessively large amounts of cut material, or to the accidental activation of the metal detector. Fortunately, blockage represented no more than $5 \%$ of harvesting time. Large stems did not seem to cause particular problem, at least within the limits explored in this study, where diameter at breast height never exceeded $150 \mathrm{~mm}$.

The stocking and productivity values above represented field averages. When measured at the single load (observation) level, both machine productivity and field stocking showed much larger variations, namely: 16.3 to 99.2 fresh $\mathrm{t} \mathrm{h}^{-1}$ for machine productivity, and 48.3 to 258.1 fresh $\mathrm{t} \mathrm{ha}^{-1}$ for field stocking. These two variables were related: regression analysis showed that machine productivity was directly proportional to field stocking and target chip length, as it could be expected (Table 3, Fig. 3). Productivity was also affected by the row system, and it was higher when harvesting twin rows rather than single rows (Table 3, Fig. 4).

Fuel use varied between 78.3 and $86.51 \mathrm{~h}^{-1}$, when related to harvesting time, excluding manoeuvres and delays. Peak values reached $95.8 \mathrm{l} \mathrm{h}^{-1}$. Hourly fuel consumption was weakly but significantly related to productivity (Fig. 5). However, fuel consumption increments were smaller than productivity increments, which resulted in an inverse relationship between productivity and fuel use per unit product. That is shown by the fourth equation posted on Table 3. Overall, fuel consumption per unit product varied from 1.3 to $2.2 \mathrm{l} \mathrm{t}^{-1}$ fresh mass and was lowest on field $\mathrm{B}$, where one recorded the highest productivity figures. Target chip length had no effect on hourly fuel consumption, whereas its effect on fuel consumption per unit product was mediated by productivity. Therefore, an additional indicator variable for target chip length introduced in equation (4) resulted non-significant due to redundancy. In any case, decreasing target chip length from $30 \mathrm{~mm}$ to $20 \mathrm{~mm}$ resulted in a $22 \%$ increase of mean fuel consumption per product unit.

Actual harvesting accounted for $62 \%$ of total worksite time (Fig. 6). That included the occasional blockage of the header, which accounted for less than $5 \%$ of harvesting time, or less than $3 \%$ of total time. For this reason, blockage was not represented in the graph. Manoeuvring represented an additional $9 \%$ of total worksite time, which brought utilization to $71 \%$. Waiting for trailers was the main cause of delays, and accounted for three quarters of total delay time, or $22 \%$ of total worksite time. The remaining delay time
Table 3

Regression equations to estimate machine productivity and fuel use.

\begin{tabular}{|c|c|c|c|c|}
\hline \multicolumn{5}{|c|}{ Equation 1 (single-rows only) } \\
\hline \multicolumn{5}{|c|}{ Productivity $=\mathrm{a}+\mathrm{b}^{*} \ln \mathrm{FS}+\mathrm{c}^{*} \mathrm{FS}^{*}$ Short } \\
\hline \multicolumn{5}{|c|}{$\mathrm{R}^{2}($ adjusted $)=0.658 ; \mathrm{n}=209$} \\
\hline & Coefficient & SE & T-Value & P-Value \\
\hline a & -204.190 & 13.144 & -15.535 & $<0.0001$ \\
\hline b & 55.177 & 2.769 & 19.925 & $<0.0001$ \\
\hline c & -0.080 & 0.01 & -8.223 & $<0.0001$ \\
\hline \multicolumn{5}{|c|}{ Equation 2 (20 mm chip length only) } \\
\hline \multicolumn{5}{|c|}{ Productivity $=\mathrm{a}+\mathrm{b} * \ln \mathrm{FS}+\mathrm{c}^{*} \mathrm{FS}^{*}$ Twin } \\
\hline \multicolumn{5}{|c|}{$\mathrm{R}^{2}($ adjusted $)=0.710 ; \mathrm{n}=109$} \\
\hline & Coefficient & SE & T-Value & P-Value \\
\hline a & -135.861 & 11.717 & -11.595 & $<0.0001$ \\
\hline b & 38.986 & 2.392 & 16.301 & $<0.0001$ \\
\hline c & 0.061 & 0.022 & 2.851 & 0.0052 \\
\hline \multicolumn{5}{|c|}{ Equation 3} \\
\hline \multicolumn{5}{|c|}{ Fuel use per hour $=\mathrm{a}+\mathrm{b}^{*}$ Productivity } \\
\hline \multicolumn{5}{|c|}{$\mathrm{R}^{2}$ (adjusted) $=0.111 ; \mathrm{n}=227$} \\
\hline & Coefficient & SE & T-Value & P-Value \\
\hline a & 75.106 & 1.468 & 51.171 & $<0.0001$ \\
\hline b & 0.134 & 0.025 & 5.394 & $<0.0001$ \\
\hline \multicolumn{5}{|c|}{ Equation 4} \\
\hline \multicolumn{5}{|c|}{ Fuel use per tonne $=\mathrm{a}+\mathrm{b}^{*}$ Productivity $^{0.93}$} \\
\hline \multicolumn{5}{|c|}{$\mathrm{R}^{2}($ adjusted $)=0.944 ; \mathrm{n}=231$} \\
\hline & Coefficient & SE & T-Value & P-Value \\
\hline a & 0.046 & 0.026 & 1.783 & 0.0759 \\
\hline b & 60.296 & 0.969 & 62.21 & $<0.0001$ \\
\hline
\end{tabular}

Notes: Productivity in $\mathrm{t}^{-1}$ fresh matter, harvesting only -manoeuvre and delays are not included; FS = Field stocking in $\mathrm{t} \mathrm{ha}^{-1}$; Short = Indicator variable for short cut length: 0 if cut $=30 \mathrm{~mm}, 1$ if cut $=20 \mathrm{~mm} ; \mathrm{SE}=$ Standard error of the coefficient; Twin = Indicator variable for twin rows: 0 if row system = single rows, 1 if row system $=$ twin rows; Fuel use per hour, in $\mathrm{l} \mathrm{h}^{-1}$ of actual harvesting work; Fuel use per tonne in $1 \mathrm{t}^{-1}$ fresh matter.

derived from organizational factors, and especially reconnaissance, instructions and the need to spare native trees occasionally growing within the plantation. Scheduled machine productivity was calculated based on total worksite time and ranged from 24 to $40 \mathrm{t}$ fresh chips per scheduled system hour. This figure did not include end-of-shift maintenance, which occupied about one hour and was conducted just after operation shut-down.

\section{Discussion and conclusions}

The high field stocking offers a good witness to the exceptional performance of Brazilian energy wood plantations. Annual yield is higher than reported for Europe, and in general for the Northern Hemisphere, where figures in the 10-12 t dry mass ha $^{-1}$ year $^{-1}$ are most common [13]. Due to the better climate and soil conditions and to the high quality of the selected plant material, the Brazilian 


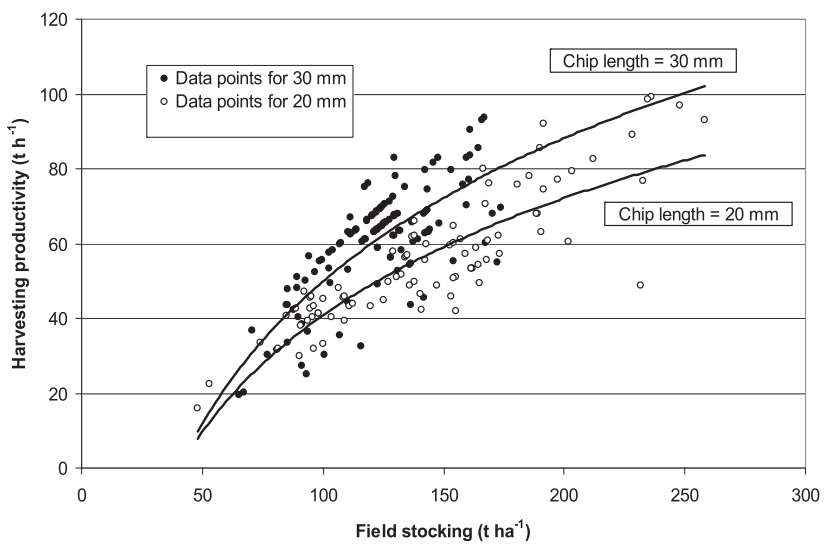

Note: Productivity in $\mathrm{th}^{-1}$ fresh matter, harvesting only -maneuver and delays are not included the regression equations were built on 209 data points and were characterized by $R^{2}=0.658$

Fig. 3. Harvesting productivity as a function of field stocking and target chip length.

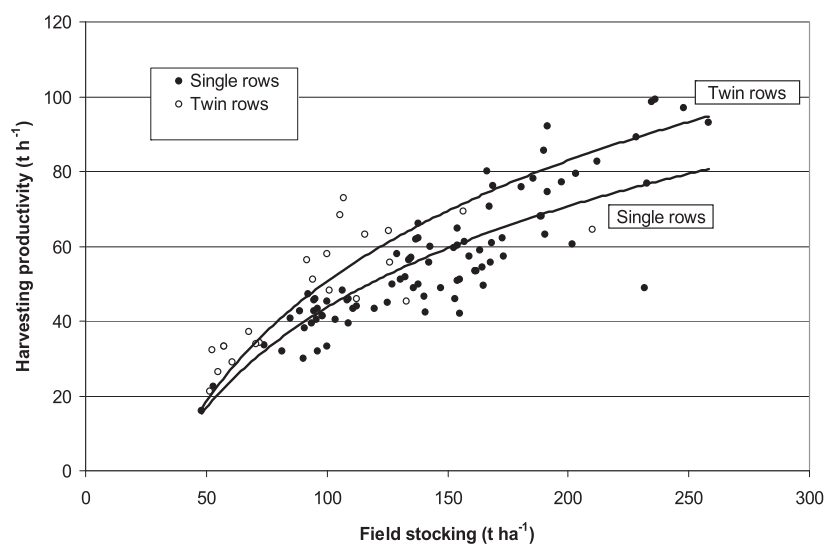

Note: Productivity in $\mathrm{th}^{-1}$ fresh matter, harvesting only -maneuver and delays are not included the regression equations were built on 109 data points and were characterized by $R^{2}=0.710$

Fig. 4. Harvesting productivity as a function of field stocking and row system.

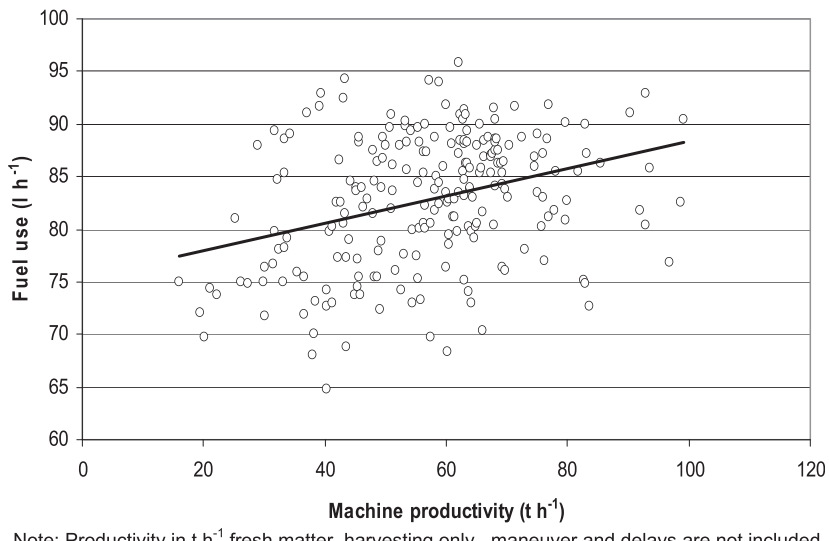

Fig. 5. Relationship between hourly fuel use and machine productivity

fields explored in this study exceeded these figures, and often produced over $18 \mathrm{t}$ dry mass ha ${ }^{-1}$ year $^{-1}$. What is more, these yields represent actual technical harvest, net of harvesting losses. Unfortunately, harvesting losses were not determined in the study, which represents a limit in the evaluation of the new machine. However, previous studies conducted with the same machine report

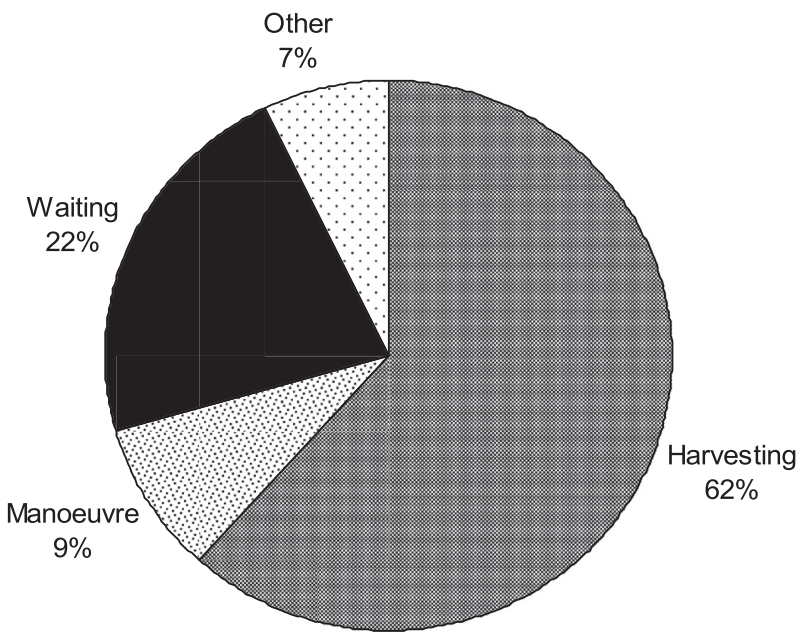

Fig. 6. Breakdown of worksite time among different activities.

relatively constant losses, which are weakly related to crop conditions $[19,20]$. These same studies estimate harvesting losses between 1 and 3 t dry matter ha ${ }^{-1}$, which should be divided by rotation age and added to the yield figures calculated here, in order to estimate actual crop yield. Furthermore, it is worth recalling that all test fields were first rotation: SRC stands generally offer lower yields during the first rotation, compared with the second and third rotations, although not all studies agree about that [20]. Therefore, the yields recorded in this study may not be representative of following rotations, which may offer an even richer crop.

Stem diameter was also much larger than the $20-40 \mathrm{~mm}$ reported for Europe and the US [13,15,21], partly because of the faster growth and partly because of all test fields being first rotation, where growth was channelled into one single stem instead of being distributed among more sprouts. Apparently, large stem size did not seem to bother the new machine, and neither did heavy field stocking. That was one of the main concerns when applying the new harvester to Brazilian plantations, which far surpassed the European ones for stem size and field stocking. One of the main merits of this study is in proving that the new harvester can negotiate lush Brazilian plantations, despite the unusually high stocking and stem size.

The graphs in Figs. 3 and 4 show that productivity keeps increasing with field stocking. Logically, reducing chip length has a negative effect on machine productivity because that requires performing more cuts per unit mass, which slows down the flow of product through the machine. Many studies conducted on conventional wood chippers offer the empirical proof of this mechanism and report machine productivity losses between 15\% [22] and $30 \%$ [23], which match quite well the 19-30\% loss recorded in this study. That may partly answer the question about the effect of chip length setting on machine performance, asked by Eisenbies et al. [24] after they had determined its effect on particle-size distribution. However, a more reliable answer could be provided after determining both effects (e.g. particle size distribution and machine performance) for the same machine and crop, which is not the case at the moment. Future studies should address this issue and provide data for both product quality and machine performance for different chip length settings, under the same work conditions.

The general increase of productivity recorded when harvesting twin rows rather than single rows could be attributed to the smaller individual tree size, resulting from the distribution of growth potential among a larger number of individuals. Foragers are designed 
Table 4

Comparison with other studies of modified foragers used on short-rotation energy plantation.

\begin{tabular}{|c|c|c|c|c|c|c|c|c|}
\hline Species & Country & $\begin{array}{l}\text { Harvester } \\
\text { Header }\end{array}$ & $\begin{array}{l}\text { Harvester } \\
\text { Forager }\end{array}$ & $\begin{array}{l}\text { Power } \\
\text { kW }\end{array}$ & $\begin{array}{l}\text { Stocking } \\
\mathrm{t} \mathrm{ha}^{-1}\end{array}$ & $\begin{array}{l}\text { Productivity } \\
\mathrm{t} \mathrm{h}^{-1}\end{array}$ & $\begin{array}{l}\text { Utilization } \\
\%\end{array}$ & Reference \\
\hline Eucalyptus & Brazil & NH 130FB & NH9060 & 441 & $90-157$ & $39-65$ & 71 & This study \\
\hline Poplar \& willow & Belgium & NH 130FB & NH9090 & 565 & 16 & 7.4 & NA & [19] \\
\hline Poplar \& willow & Germany & NH 130FB & NH9050-60 & $368-435$ & $36-84$ & $32-61$ & $28-68$ & [31] \\
\hline Willow & USA & NH 130FB & NH9080 & 390 & $43-70$ & $70-77$ & 64 & [21] \\
\hline Poplar & Italy & Claas HS2 & Claas $840-60$ & $254-306$ & $7-72$ & $11-56$ & 79 & [15] \\
\hline Poplar & Italy & GBE & Claas $880-90$ & $340-445$ & $15-117$ & $22-92$ & 79 & [15] \\
\hline Poplar \& willow & Italy & Biopoplar & JD 7400 & 330 & $51-63$ & $25-61$ & 83 & [13] \\
\hline Poplar \& willow & Italy & HTM 1500 & Krone Big X & 440 & $30-98$ & $45-62$ & 90 & [13] \\
\hline
\end{tabular}

Notes: $\mathrm{t}=$ fresh tonnes; Utilization = productive work time (e.g. harvest and turn) over total worksite time; NA = Not available.

to harvest grass rather than trees, and one may expect that they perform best when dealing with many small stems, instead of few large ones - all the rest being equal [15].

The fact that all fields were first rotation must be considered very carefully when evaluating the results of this study. If the presence of single large stems may strain the harvesting unit, it is also true that handling multiple stems represents a separate and additional challenge, and this study did not test the performance of the new harvester when applied to multi-stem eucalyptus stools. Previous tests conducted with poplar and willow in the US indicate that the New Holland harvester can handle quite well both stand types, but the present study did not test the effect of stand type (single vs. multi-stem) and therefore it cannot provide conclusive proof of indifference.

The data obtained from this experiment is corroborated by the comparison with the results of previous studies (Table 4). These studies cover poplar or willow, which present substantially lower field stocking conditions. The high field stocking conditions offered by Brazilian eucalyptus are approached - but never equalled - only by the best Italian poplar clones. The machine productivity figures obtained in this study are well within the range spanned by previous studies, which is very wide and extends between 7 and 90 fresh $\mathrm{t} \mathrm{h}^{-1}$. However, central values are between 30 and 60 fresh $\mathrm{t}$ $\mathrm{h}^{-1}$, which match very well the values recorded in this study. In that regard, one may point out that some of the best performance figures found in recent bibliography come from commercial operations, where long-term driver experience likely plays a major role. In contrast, the driver in this test was well acquainted with the base machine, but had been driving it on the eucalyptus energy plantations for few weeks before commencing the test proper. Therefore, one may expect significant productivity improvements as Brazilian operators gain experience with the new technique, and it is very likely that the same test repeated after several months of prolonged use with eucalyptus would produce different and better results.

The utilization level recorded in this study is in line with one may expect from this type of operations (Table 4). Slightly higher utilization levels characterize the Italian studies, which were the only ones conducted on routine commercial operations. All the other figures reflect experimental operations that still needed some fine-tuning at system level. Waiting for trailers is the most important source of delays in all cases, and the more so in the experimental set-ups. Therefore, one may expect small increments in utilization as well, although current figures are quite good already.

Only another study offers information about the fuel consumption of a modified forager used for harvesting short rotation coppice [31]. That study deals with the same New Holland harvester as presented in this study, and reports a fuel consumption of $3.5 \mathrm{l} \mathrm{t}^{-1}$ dry matter, or $1.6 \mathrm{l}$ fresh $\mathrm{t}^{-1}$, which is much similar to the figures presented here. Concerning fuel consumption, it is important to warn readers that the statistical power of equation (4) (Table 3) might be weakened by some degree of intercorrelation, as suggested by the unrealistically high $\mathrm{R}^{2}$. However, equation (3) was retained because it offers a good expression of a logical and strong relationship, whether it be stochastic or deterministic.

Of course, modified foragers are not the only option. SRC can be harvested with a large array of different machines, including cutand-collect [25] and/or pull-type units [26,27]. However, recent studies demonstrate that modified foragers represent the most effective option by far $[19,28]$. Cut-and-chip technology does have the limit of producing fresh chips, which have a lower energy content [29] and are subject to rapid decay [30]. However, these drawbacks can be mitigated by immediate use after blending with drier feedstock, while moisture content itself may not be an obstacle for use in new generation bio-refineries [24].

In general, this study has the merit of demonstrating that stateof-the-art cut-and-chip technology can be effectively deployed on Brazilian energy plantations, despite their exceptionally high stocking and stem size. Modern powerful foragers can effectively negotiate the conditions offered by first-rotation SRC eucalyptus, regardless of spacing and row system (e.g. single or twin). Further studies should be conducted on following rotations, in order to determine the effect of smaller stem size and - possibly - of higher field stocking levels.

\section{Acknowledgements}

The authors acknowledge the support of Case New Holland that made available their machine for the tests.

\section{References}

[1] T.M. Fenning J. Gershenzon, Where will the wood come from? Plantation forests and the role of biotechnology, Trends Biotech. 20 (7) (2002) 291-296.

[2] R.A. Sedjo, The potential of high-yield plantation forestry for meeting timber needs, New For. 17 (1-3) (1999) 339-360.

[3] J. Korhonen, A. Toppinen, F. Cubbage, J. Kuuluvainen, Factors driving investment in planted forests: a comparison between OECD and non-OECD countries, Int. For. Rev. 16 (1) (2014) 67-77.

[4] J.P. Siry, F.W. Cubbage, M.R. Ahmed, Sustainable forest management: global trends and opportunities, For. Pol. Econ. 7 (2005) 551-561.

[5] FAO, Responsible Management of Planted Forests: Voluntary Guidelines Preparation for Action - the Country Level Methodology, Planted Forests and Tree Working Paper 45/E, FAO, Rome, 2009.

[6] J. Stape, D. Binkley, M. Ryan, S. Fonseca, R. Loos, E. Takahashi, C. Silva, S. Silva, R. Hakamada, J. Ferreira, A. Lima, J. Gava, F. Leite, H. Andrade, J. Alves, G. Silva M. Azevedo, The Brazil eucalyptus potential productivity project: influence of water, nutrients and stand uniformity on wood production, For. Ecol. Manag. 259 (2010) 1684-1694.

[7] P. Fearnside, Plantation forestry in Brazil: projections to 2050, Biomass Bioenerg. 15 (1999) 437-450.

[8] IBA (Brazilian Tree Industry), Annual Report, Base Year 2014, Indústria Brasileira de Árvores, São Paulo, Brazil, 2015, p. 64.

[9] E. Campinhos Jr., Sustainable plantations of high-yield shape eucalyptus trees for production of fiber: the Aracruz case, New For. 17 (1999) 129-143.

[10] L. Couto, I. Nicholas, L. Wright, Short Rotation Eucalypt Plantations for Energy in Brazil, IEA Bioenergy Task 43 Report 2, 2011, p. 17. 
[11] R. Gonzalez, T. Treasure, J. Wright, D. Saloni, R. Phillips, R. Abt, H. Jameel, Exploring the potential of Eucalyptus for energy production in the Southern United States: financial analysis of delivered biomass. Part I, Biomass Bioenerg. 35 (2011) 755-766.

[12] S. Guerra, E. Garcia, K. Lanças, M. Rezende, R. Spinelli, Heating value of eucalyptus wood grown on SRC for energy production, Fuel 137 (2014) 360-363.

[13] R. Spinelli, N. Magagnotti, G. Picchi, C. Lombardini, C. Nati, Upsized harvesting technology for coping with the new trends in short-rotation coppice, Appl. Eng. Agric. 27 (2011) 551-557.

[14] B. Danfors, S. Ledin, H. Rosenqvist, Short-rotation Willow Coppice Grower Manual, Swedish Institute of Agricultural Engineering, Uppsala, Sweden, 1998, 1988.

[15] R. Spinelli, C. Nati, N. Magagnotti, Using modified foragers to harvest shortrotation poplar plantations, Biomass Bioenerg. 33 (2009) 817-821.

[16] T. Volk, L. Abrahamson, C. Nowak, L. Smart, P. Tharakan, E. White, The development of short-rotation willow in the northeastern United States fo bioenergy, bioproducts, agroforestry and phytoremediation, Biomass Bioenerg. 30 (2006) 715-727.

[17] N. Magagnotti, C. Kanzian, F. Schulmeyer, R. Spinelli, A new guide for work studies in forestry, Int. J For. Eng. 24 (2013) 249-253.

[18] R. Spinelli, R. Visser, Analyzing and estimating delays in wood chipping operations, Biomass Bioenerg. 33 (2009) 429-433.

[19] G. Berhongaray, O. El Kasmioui, R. Ceulemans, Comparative analysis of harvesting machines on an operational high-density short rotation woody crop (SRWC) culture: one-process versus two-process harvest operation, Biomass Bioenerg. 58 (2013) 333-342.

[20] N.J. Sleight, T.A. Volk, G.A. Johnson, M.H. Eisenbies, S. Shi, E.S. Fabio, Pooler PS change in yield between first and second rotations in willow (Salix spp.) biomass crops is strongly related to the level of first rotation yield, Bioenerg. Res. (2015), http://dx.doi.org/10.1007/s12155-015-9684-0.

[21] M.H. Eisenbies, T.A. Volk, J. Posselius, C. Foster, S. Karapetyan, S. Shi,
Evaluation of a single-pass, cut and chip harvest system on commercial-scale, short-rotation shrub willow biomass crops, Bioenerg. Res. (2014), http:// dx.doi.org/10.1007/s12155-014-9482-0.

[22] R. Spinelli, N. Magagnotti, The effect of raw material, cut length, and chip discharge on the performance of an industrial chipper, For. Prod. J 62 (2012) 584-589.

[23] A. Facello, E. Cavallo, N. Magagnotti, G. Paletto, R. Spinelli, The effect of knife wear on chip quality and processing cost of chestnut and locust fuel wood, Biomass Bioenerg. 59 (2013) 468-476.

[24] M. Eisenbies, T. Volk, J. Posselius, S. Shi, A. Patel, Quality and variability of commercial-scale short rotation willow biomass harvested using a single-pass cut-and-chip forage harvester, Bioenerg. Res. 8 (2015) 546-559.

[25] V. Civitarese, R. Spinelli, M. Barontini, F. Gallucci, E. Santangelo, A. Acampora, A. Scarfone, A. Del Giudice, L. Pari, Open-air drying of cut and windrowed short-rotation poplar stems, Bioenerg. Res. (2015), http://dx.doi.org/10.1007/ s12155-015-9612-3, 2015.

[26] P. Savoie, P. Hébert, F. Robert, D. Sidders, Harvest of short-rotation woody crops in plantations with a Biobaler, Energ Power Eng. 5 (2013) 39-47.

[27] P. Savoie, P.L. Herbert, F.S. Robert, Novel Willow Header Adapted to a Pulltype Forage Harvester: Development and Field Experiments, ASABE 2014, Montreal, Quebec Canada, 2014, p. 14

[28] R. Pecenka, T. Hoffmann, Harvest technology for short rotation coppice and costs of harvest, transport and storage, Agron. Res. 13 (2015) 361-371.

[29] R. Pecenka, H. Lenz, C. Idler, W. Daries, D. Ehlert, Development of bio-physical properties during storage of poplar chips from 15 ha test fields, Biomass Bioenerg. 65 (2014) 13-19.

[30] M. Barontini, A. Scarfone, R. Spinelli, F. Gallucci, E. Santangelo, A. Acampora, R. Jirjis, V. Civitarese, L. Pari, Storage dynamics and fuel quality of poplar chips, Biomass Bioenerg. 62 (2014) 17-25.

[31] J. Schweier, G. Becker, New Holland's forage harvester productivity in shortrotation coppice: evaluation of field studies from a German perspective, Int. J For. Eng. 23 (2012) 82-88. 